\title{
Aa. Vv., «L'CEil bleu», n. 11
}

\section{Ida Merello}

\section{(2) OpenEdition}

\section{Journals}

\section{Edizione digitale}

URL: http://journals.openedition.org/studifrancesi/6062

DOI: 10.4000/studifrancesi.6062

ISSN: 2421-5856

\section{Editore}

Rosenberg \& Sellier

\section{Edizione cartacea}

Data di pubblicazione: 1 mai 2011

Paginazione: 204

ISSN: 0039-2944

\section{Notizia bibliografica digitale}

Ida Merello, «Aa. VV., «L'CEil bleu», n. 11», Studi Francesi [Online], 163 (LV | I) | 2011, online dal 30

novembre 2015, consultato il 12 janvier 2021. URL: http://journals.openedition.org/studifrancesi/6062 ; DOI: https://doi.org/10.4000/studifrancesi.6062

Questo documento è stato generato automaticamente il 12 janvier 2021.

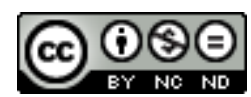

Studi Francesi è distribuita con Licenza Creative Commons Attribuzione - Non commerciale - Non opere derivate 4.0 Internazionale. 


\title{
Aa. Vv., «L'CEil bleu», n. 11
}

\author{
Ida Merello
}

\section{NOTIZIA}

«L'Æil bleu», n. 11, juin 2010, pp. 104.

1 Questa raffinata pubblicazione per specialisti e lettori di gusto, che sembra rivaleggiare col preziosismo dell'ambiente fin de siècle cui si richiama, offre in questo decimo fascicolo alcune deliziose chicche: in apertura, Benoît Houzé (Tristan tous genres, pp. 3-22) ci presenta l'attività artistica di Corbière, legata alle arti decorative, e ispirata alla tradizione bretone, per cui dipinge ad esempio un autoritratto su un piatto in ceramica di Quimper, o progetta la scultura di una splendida testiera di letto in legno, dai lati scolpiti da Georges Lacombe. Questo permette all'A. di mostrare il legame di Corbière coi Nabis; mentre un piccolo corpus scelto di testi consente di far luce sulle concezioni pittoriche del poeta. In annesso, un capitolo del romanzo Au pôle et autour du pôle di Louis Noir dove interviene il personaggio di Corbière. Henri BoRDILLoN (Gustave Le Rouge, œuvre poétique, pp. 23-60) offre un'interessante antologia poetica di Gustave Le Rouge, accompagnata da indicazioni filologiche e alcune intriganti illustrazioni. paul SCHNEEBELI conclude invece un contributo su André Veidaux iniziato nel numero precedente, e suddiviso ora in due parti: A.V. anarchiste éclectique e A.V et la famille. Ugualmente pregevole la sezione della bibliografia delle riviste, dedicata a «La revue d'un passant» (1892-1906), con la pubblicazione di quattro sonetti del suo direttore F.-B. de Bucé. 